\title{
Sistem Pencatatan Penilaian Rapor Siswa Berdasarkan Kurikulum 2013 (Studi Kasus MIN Pasar Baru Bintuhan)
}

\author{
Ricky Zulfiandri ${ }^{1}$, Amir Mahmud ${ }^{2}$ \\ ${ }^{1,2}$ Program Studi Sistem Informasi, Universitas Dehasen Bengkulu \\ Email : ricky.zulfiandry@gmail.com
}

\begin{abstract}
Report card is reporting student grades that have been obtained by the student for taking education in one semester.Pencatatan grades involve various stakeholders in the school, including homeroom, teachers of subjects and curriculum officials. State Islamic Elementary School Pasar Baru Bintuhan is one madrassa or public schools that have implemented the curriculum of 2013. This also resulted in changes to the format of the report card. The purpose of this research is to create a system that can be used for recording student assessment report based Curriculum 2013 in State Islamic Elementary School Pasar Baru Bintuhan. The method used in this research is the method of system development with the aim to improve and streamline the existing system. The first step in building this new system is to conduct a needs analysis of data, collecting data, designing using structured modeling, implementing design into a form of Diagram Alir Data, Entity Relationship Diagram, the Design File, Design Input, Design Output and Implementation into an application system for recording grades report card using the programming language PHP and MySQL database. In accordance with the results of the testing system, the Recording System Application Based Curriculum Assessment Report Card Student 2013 at the State Islamic Elementary School Pasar Baru Bintuhan has been going well as planned in the design of the system.
\end{abstract} Keyword : grades, report cards, school, php, mysql

Intisari-Rapor merupakan laporan nilai siswa yang telah didapatkan oleh siswa selama menempuh pendidikan dalam satu semester. Pencatatan nilai rapor melibatkan berbagai pihak di sekolah, diantaranya wali kelas, guru pelajaran, dan pejabat kurikulum. Madrasah Ibtidaiyah Negeri (MIN) Pasar Baru Bintuhan adalah salah satu madrasah atau sekolah negeri yang telah mengimplementasikan kurikulum 2013. Hal ini juga berdampak pada perubahan format rapor. Tujuan penelitian ini adalah untuk membuat sistem yang dapat digunakan untuk pencatatan penilaian rapor siswa berdasarkan Kurikulum 2013 di MIN Pasar Baru Bintuhan. Metode penelitian yang digunakan dalam penelitian ini adalah metode pengembangan sistem dengan tujuan meningkatkan dan mengefektifkan sistem yang sudah ada. Langkah yang dilakukan dalam membangun sistem baru ini yaitu dengan melakukan analisis kebutuhan data, mengumpulkan data, merancang dengan menggunakan pemodelan terstruktur, mengimplementasi rancangan ke dalam sebuah bentuk Diagram Alir Data, Entity Relationship Diagram, Rancangan File, Rancangan Input, Rancangan Output dan Implementasi kedalam sebuah aplikasi sistem pencatatan nilai rapor menggunakan bahasa pemrograman PHP dan database MySQL.Sesuai dengan hasil pengujian sistem, maka Aplikasi Sistem Pencatatan Penilaian Rapor Siswa Berdasarkan Kurikulum 2013 pada MIN Pasar Baru Bintuhan telah berjalan dengan baik sesuai dengan yang direncanakan pada perancangan sistem.

Kata Kunci : nilai, rapor, sekolah, php, mysql

\section{PENDAHULUAN}

Rapor merupakan laporan nilai siswa yang telah didapatkan oleh siswa selama menempuh pendidikan dalam satu semester. Pencatatan nilai rapor melibatkan berbagai pihak di sekolah, diantaranya wali kelas, guru pelajaran, dan pejabat kurikulum. Madrasah Ibtidaiyah Negeri (MIN) Pasar Baru Bintuhan adalah salah satu madrasah atau sekolah negeri yang telah mengimplementasikan kurikulum 2013. Hal ini juga berdampak pada perubahan format rapor.

MIN Pasar Baru Bintuhan telah dilengkapi dengan fasilitas teknologi komputer dan jaringan yang memadai, namun belum dimanfaatkan dalam sistem kerja yang berbasis jaringan. Hal ini dikarenakan belum adanya aplikasi yang mendukung dalam pengeolahan data yang berbasis ja- 
ringan.

Berdasarkan uraian diatas penulis tertarik untuk mengangkat judul skripsi yaitu "Sistem Pencatatan Penilaian Rapor Siswa Berdasarkan Kurikulum 2013 (Study Kasus MIN Pasar Baru Bintuhan)".

\section{LANDASAN TEORI}

\section{A. Sistem}

Menurut Febrian (2004:398), sistem (system) adalah suatu jaringan kerja dari prosedur-prosedur yang saling berhubungan, berkumpul bersama-sama untuk melakukan suatu kegiatan atau untuk menyelesaikan suatu sasaran tertentu.

\section{B. Rapor}

Menurut Kamus Besar Bahasa Indonesia rapor adalah buku yang berisi nilai kepandaian dan prestasi belajar murid di sekolah, berfungsi sebagai laporan guru kepada orang tua atau wali murid.

\section{PHP}

Menurut Oktavian (2010:31), PHP adalah akronim dari Hypertext Preprocessor, yaitu suatu bahasa pemrograman berbasiskan kode-kode ( $s c$ ript) yang digunakan untuk mengolah suatu data dan mengirimkannya kembali ke web browser menjadi kode HTML.

\section{MYSQL}

Menurut Andi (2010:5), MySQL adalah aplikasi yang bersifat daemon atau menetap dalam memori yang berjalan bersama dengan sistem operasi MicrosoftWindows. Interface utama MySQL database server adalah commad line atau berbasis DOS sehingga diperlukan pengetahuan khusus mengenai penggunaan perintah atau command dalam command shell MySQL.

\section{E. Database Management System (DBMS)}

Untuk mengelola basis data diperlukan perangkat lunak yang disebut DBMS. DBMS adalah perangkat lunak sistem yang memungkinkan para pemakai membuat, memelihara, mengontrol, dan mengakses basis data dengan cara yang praktis dan efisien. DBMS dapat digunakan untuk mengakomodasi berbagai macam pemakai yang memiliki kebutuhan yang berbeda-beda. Beberapa contoh DBMS yaitu: Access, DB2, Informix, Ingres, MySQL, Oracle, PostgreSQL, dan Sybase.

\section{F. Diagram Alir Data (DAD)}

Menurut Sutabri (2004:162) DAD merupakan alat bantu yang dapat digunakan untuk menggambarkan aliran data informasi dan transformasi (proses) dari data dimulai dari pemasukan data sampai menghasilkan keluaran (output) data.

\section{G. Entity Relationship Diagram (ERD)}

Menurut Simarmata (2007:96) Entity Relationship Diagram (ERD) model data konseptual yang memandang dunia nyata sebagai kesatuan (entities) dan hubungan (relationship).

\section{METODOLOGI PENELITIAN}

\section{A. Subjek Penelitian}

Madrasah di dirikan diatas tanah yang dulunya merupakan hibah dari Pemerintahan daerah Kecamatan kaur selatan dengan luas $1105 \mathrm{M}^{2}$, adapun dipakai sekarang bangunan seluas tanah yang ada. Setelah madrasah ini mengalami pergantian pengurus priode demi priode, maka pada tahun 1997 berubah menjadi Madrasah Ibtidaiyah Negeri Pasar Baru Bintuhan yang berestatus Negeri di bawah pimpinan Zainudin, A.Md sampai pada tahun 2002. Kemudianmadrasah ini pergatian kepengurusan di bawah pimpinan Ahzam,A. Ma sampai pada tahun 2009. Kemudianmadrasah ini kembali pergatian kepengurusan di bawah pimpinan Hasan Yahya, S,Pd sampai tahun 2011, dengan berkembang pendidikan dan di pegang oleh Ahmadi, M.Pd tersebut sedang diupayakan meningkatkan mutu pendidikan dan pengajaran serta berupaya untuk menarik minat masyarakat supaya ada kesan positif serta nilai lebih dalam menempuh pendidikan di Madrasah Ibtidaiyah 
Negeri Pasar Baru Bintuhan.

\section{B. Tempat dan Waktu Penelitian}

Penelitian ini dilakukan MIN Pasar Baru Bintuhan yang beralamat di Desa Pasar Baru Kecamatan Kaur Selatan Kabupaten Kaur Provinsi Bengkulu. Pelaksanaan pra penelitian dilaksanakan mulai bulan Januari 2016 sampai dengan bulan Febuari 2016, dan penelitian selanjutnya akan dilaksanakan pada bulan Mei 2016 sampai dengan Juni 2016.

\section{Metode Penelitian}

Langkah yang dilakukan dalam membangun sistem baru ini yaitu dengan melakukan analisis kebutuhan data, mengumpulkan data, merancang dengan menggunakan pemodelan terstruktur, mengimplementasi rancangan ke dalam sebuah bentuk DAD, ERD, Rancangan File, Rancangan Input, Rancangan Output dan Implementasi kedalam sebuah aplikasi sistem pencatatan nilai rapor menggunakan bahasa pemrograman PHP dan $d a-$ tabase MySQL.

\section{Metode Pengumpulan Data}

1. Metode Observasi

2. Wawancara

3. Metode Studi Pustaka

\section{E. Metode Perancangan Sistem}

1. Analisa Sistem Aktual

2. Analisa Sistem Baru

\section{1) Diagram Konteks}

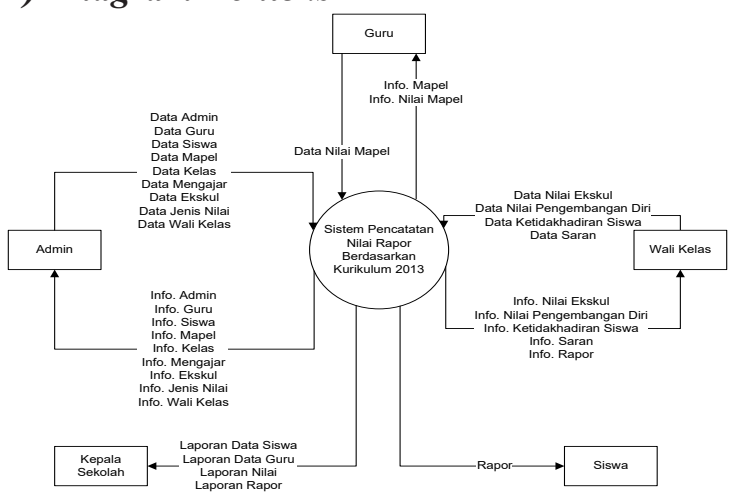

2) DAD Level 0

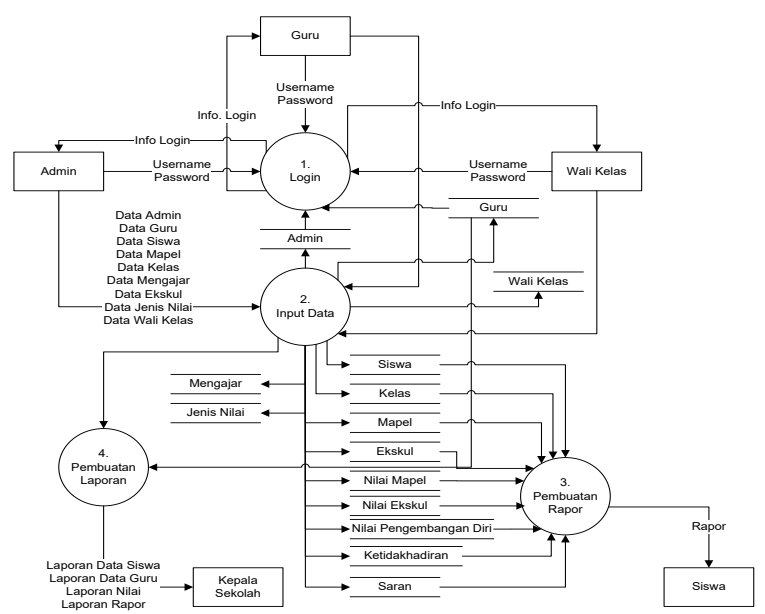

3) DAD Level 1 (Proses Login)

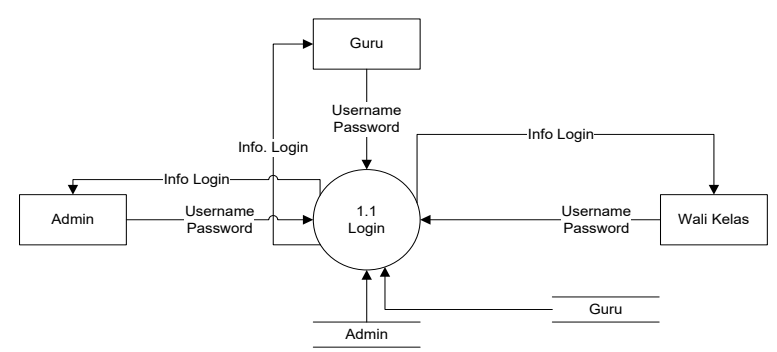

4) DAD Level 1 (Proses Input Data)

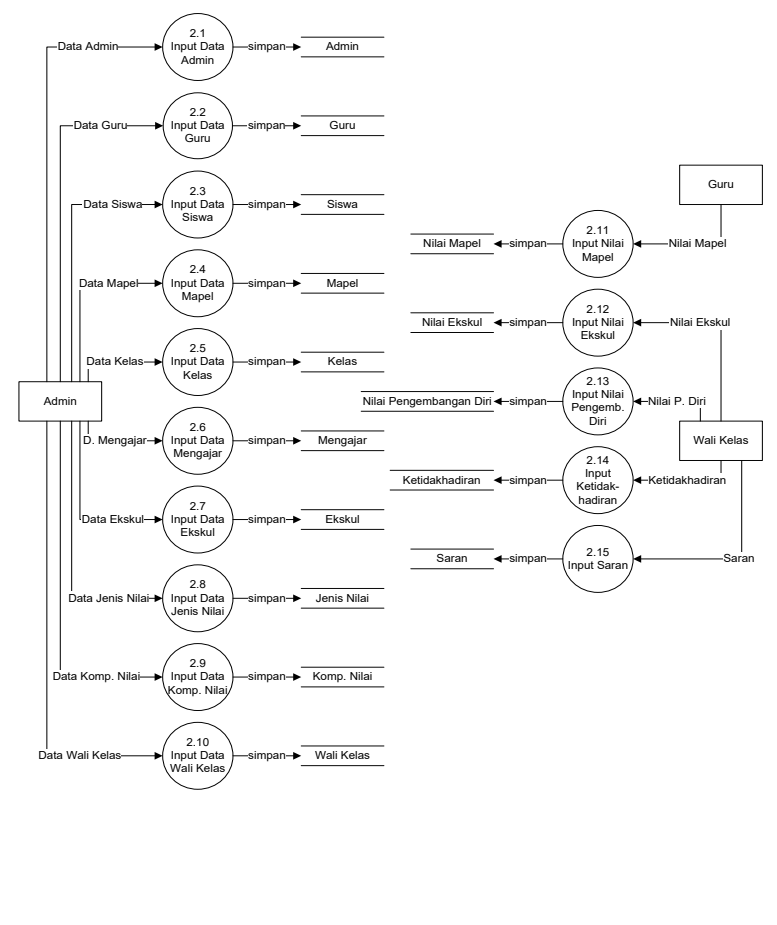


5) DAD Level 1 (Proses Pembuatan Rapor Siswa)

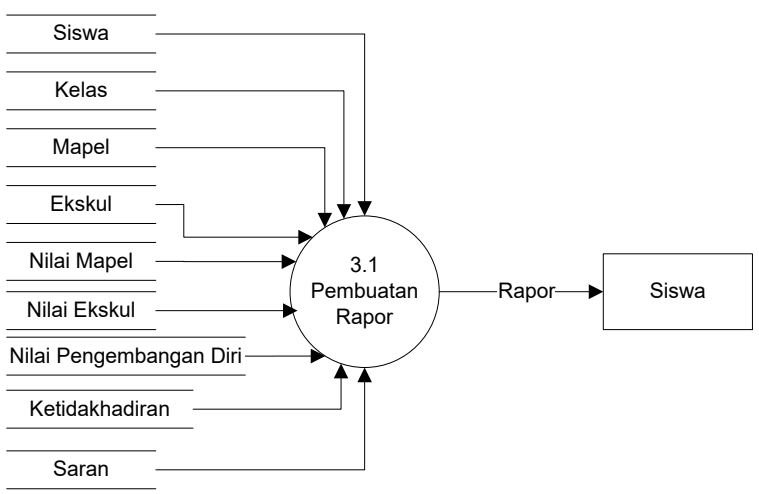

6) DAD Level 1 (Proses Pembuatan Laporan)

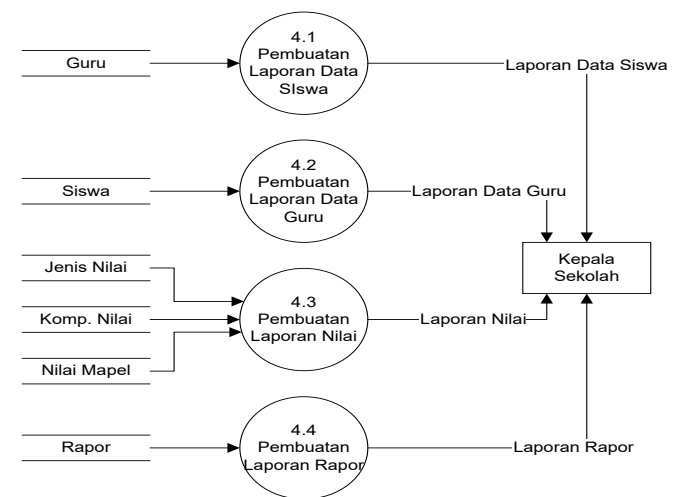

7) Entity Relationship Diagram

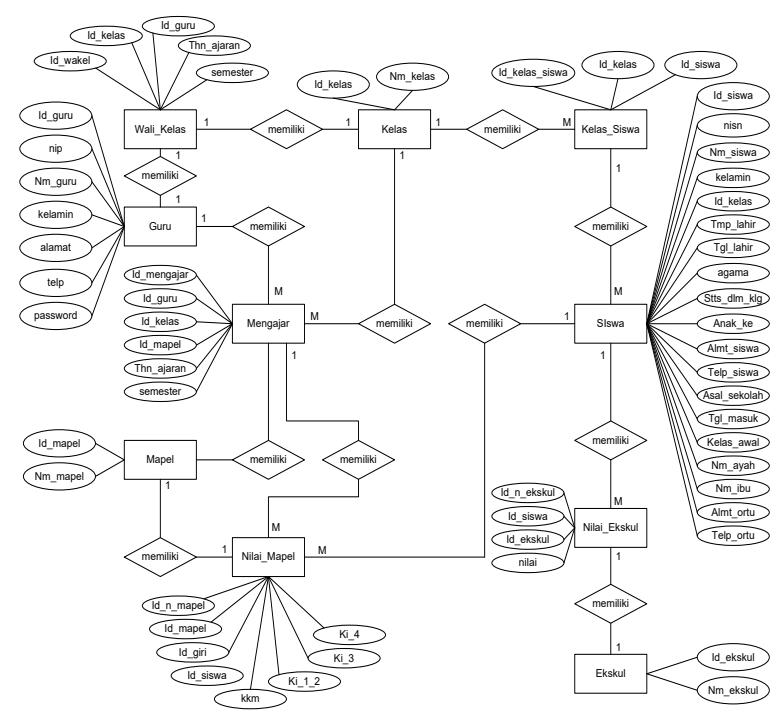

8) Rancangan Struktur Menu

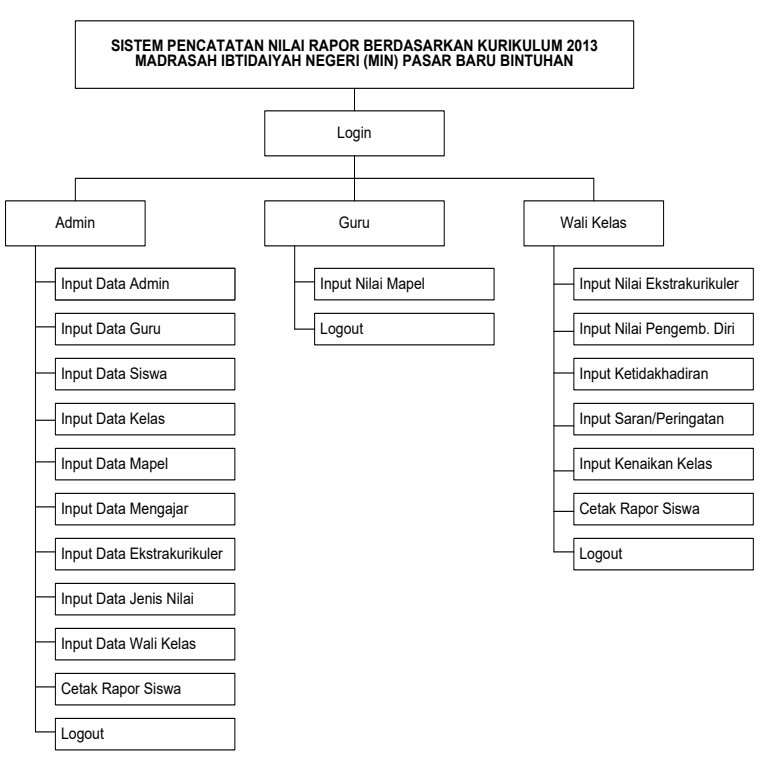

\section{9) Rancangan Tampilan Halaman Login}

\begin{tabular}{|c|c|c|}
\hline Logo & \multicolumn{2}{|c|}{$\begin{array}{l}\text { SISTEM PENCATATAN NILAI RAPOR BERDASARKAN KURIKULUM } 2013 \\
\text { MADRASAH IBTIDAIYAH NEGERI (MIN) PASAR BARU BINTUHAN } \\
\text { Desa Pasar Baru Kec. Kaur Selatan Kab. Kaur Provinsi Bengkulu }\end{array}$} \\
\hline \multicolumn{2}{|r|}{ LOGIN } & PETUNJUK \\
\hline $\begin{array}{l}\text { Username } \\
\text { Password }\end{array}$ & $X X X-20-X X X$ & 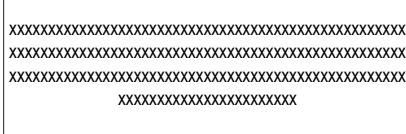 \\
\hline \multicolumn{3}{|c|}{ Copyright 2016 - MIN Pasar Baru Bintuhan (Created By : Amir Mahmud) } \\
\hline
\end{tabular}

\section{0) Rancangan Tampilan Menu Utama}

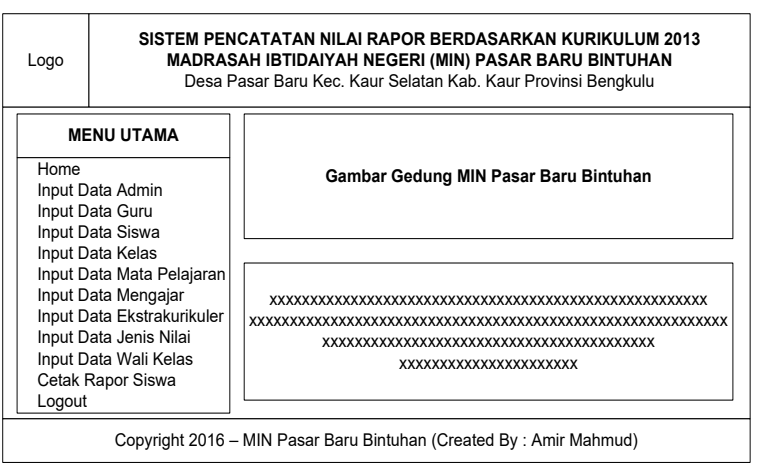




\section{1)Rancangan Menu Utama (Guru)}

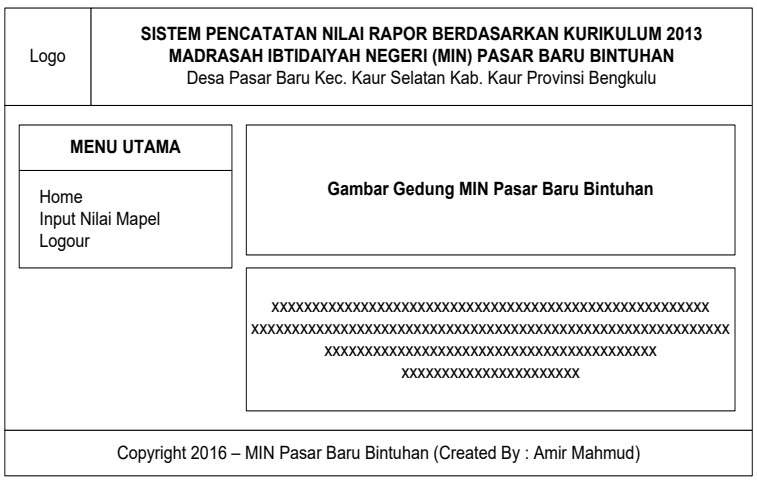

\section{2) Rancangan Menu Utama (Wali Kelas)

\begin{tabular}{|c|c|c|}
\hline Logo & $\begin{array}{c}\text { SISTEM PENCATATAN NILAI RAPOR BERDASARKAN KURIKULUM } 2013 \\
\text { MADRASAH IBTIDAIYAH NEGERI (MIN) PASAR BARU BINTUHAN } \\
\text { Desa Pasar Baru Kec. Kaur Selatan Kab. Kaur Provinsi Bengkulu }\end{array}$ \\
\hline
\end{tabular}

\begin{tabular}{|c|c|}
\hline MENU UTAMA & \\
\hline \multirow{2}{*}{$\begin{array}{l}\text { Home } \\
\text { Input Nilai Ekstrakurikuler } \\
\text { Input Nilai Pengembangan Diri } \\
\text { Input Ketidakhadiran } \\
\text { Input Saran/Peringatan } \\
\text { Input Kenaikan Kelas } \\
\text { Cetak Rapor Siswa } \\
\text { Logout }\end{array}$} & Gambar Gedung MIN Pasar Baru Bintuhan \\
\hline & 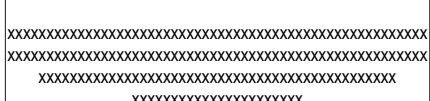 \\
\hline Copyright 2016 - M & ar Baru Bintuhan (Created By : Amir Mahmud) \\
\hline
\end{tabular}

\section{3) Rapor Siswa}

KETERANGAN TENTANG DIRI SISWA

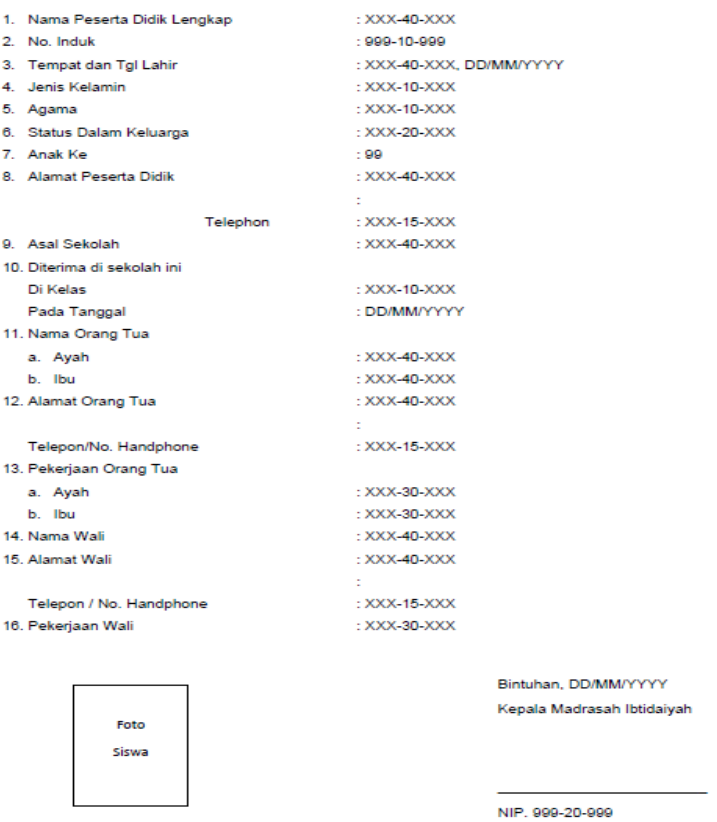

\section{4) Rapor Siswa Semester Ganjil}

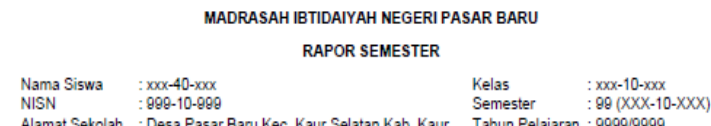

Alamat Sekolah : Desa Pasar Baru Kec. Kaur Selatan Kab. Kaur Tahun Pelajaran : $: 98$ (XXX-10-XXX)

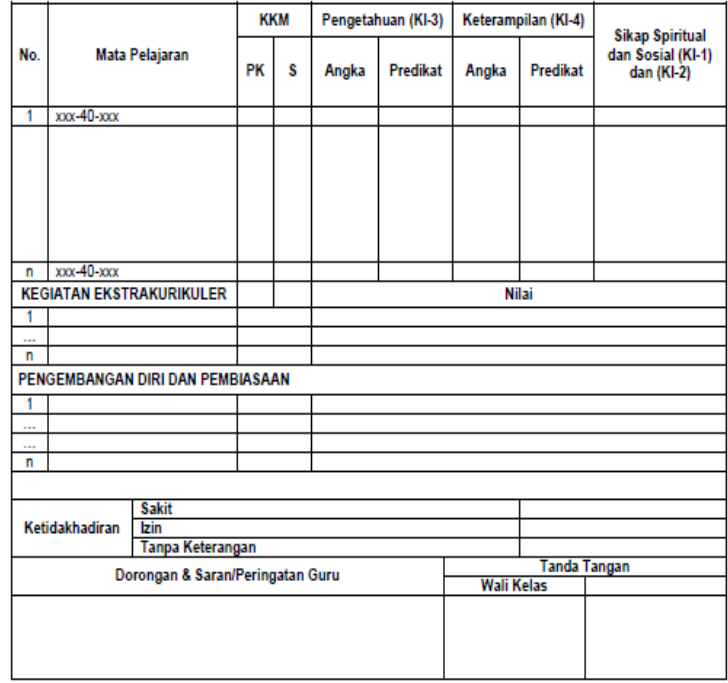

Kepala Madrasah Wali Kelas,

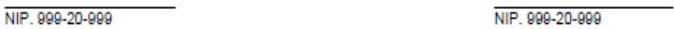

\section{5) Rapor Siswa Semester Genap}

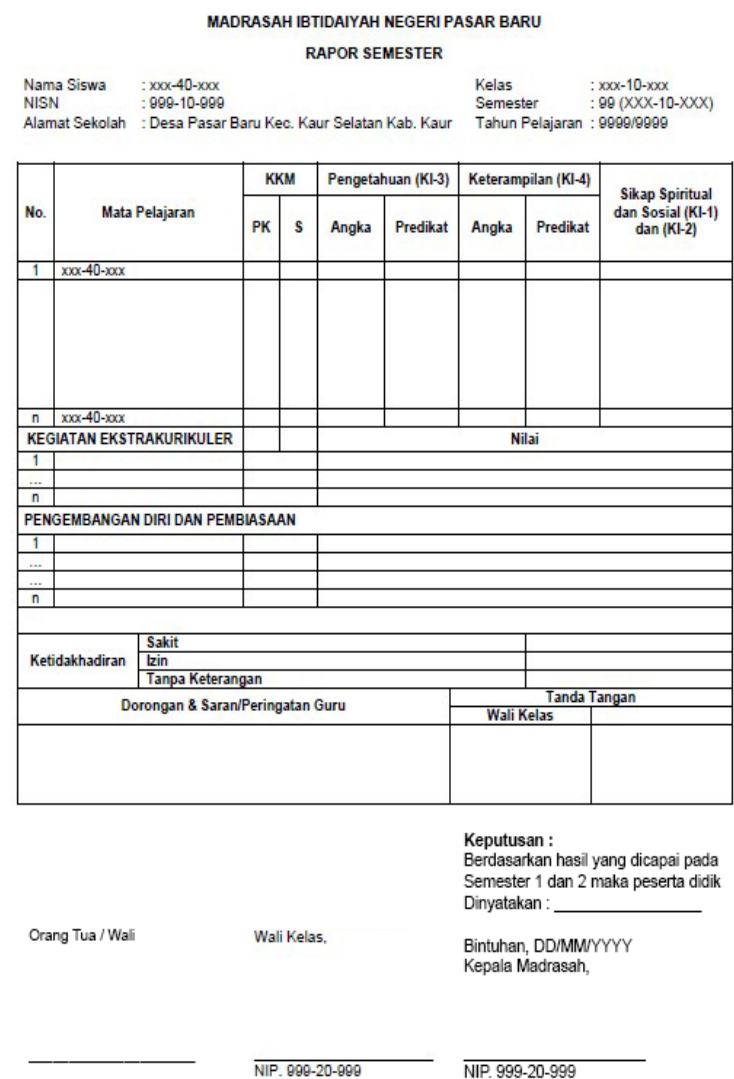




\section{6) Flowchart Program}

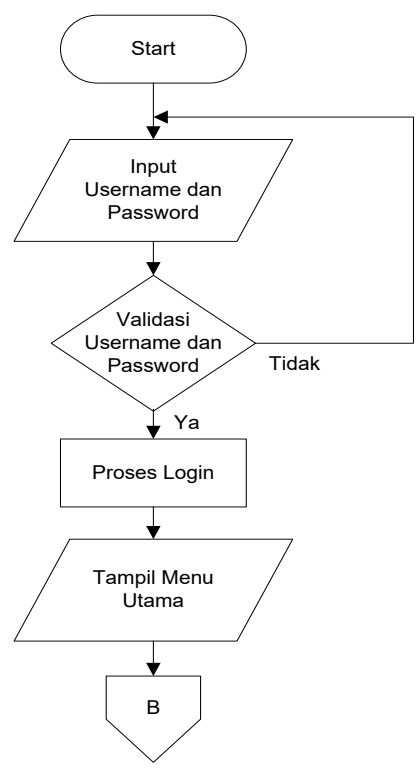

\section{7) Flowchart Proses}

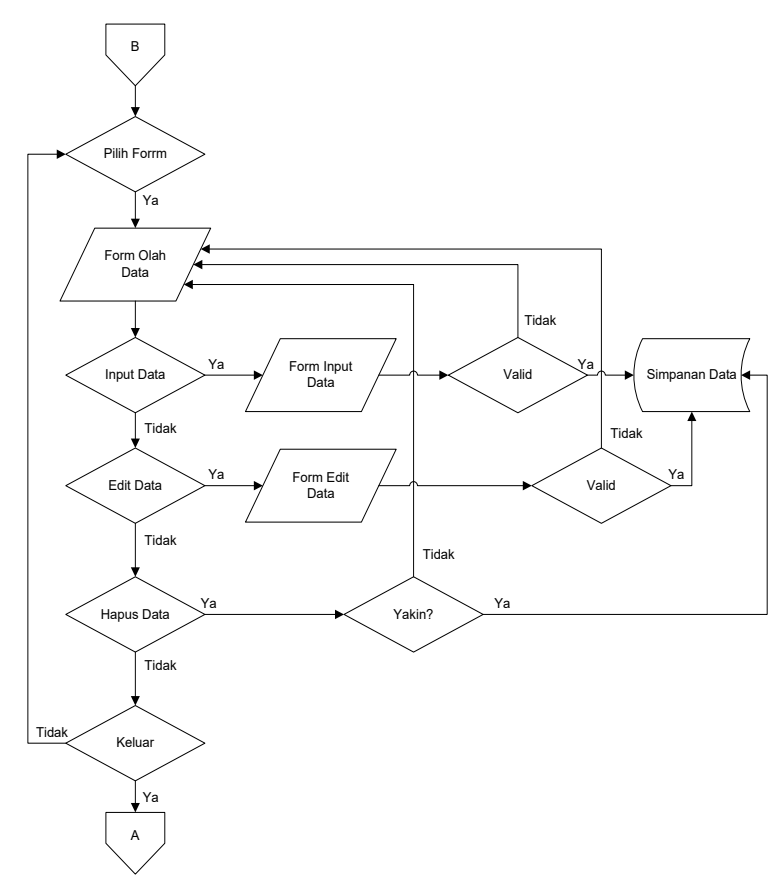

\section{HASIL DAN PEMBAHASAN}

Sistem Pencatatan Penilaian Rapor Siswa Berdasarkan Kurikulum 2013 yang dibagun pada MIN Pasar Baru Bintuhan merupakan aplikasi yang digunakan untuk mengelola nilai raport pada akhir semester, dimana pengguna yang terlibat di dalamnya adalah admin yang dalam hal ini dipegang oleh bagian kurikulum dan juga guru yang bertugas menginput nilai pada mata kuliah yang diajar.

\section{A. Lagin Admin}

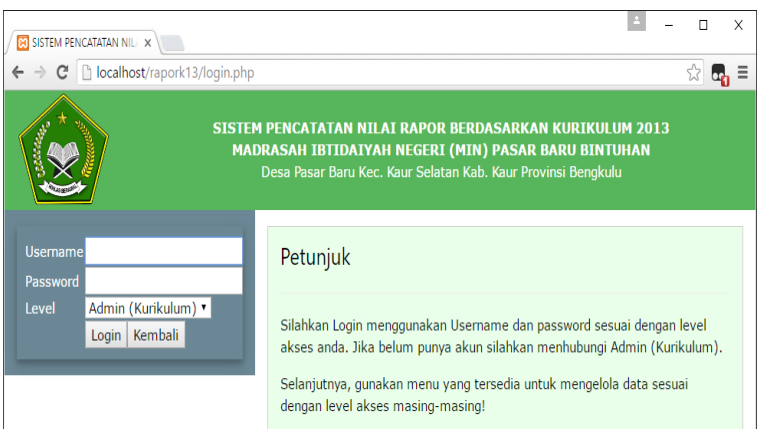

\section{B. Menu Utama Admin}

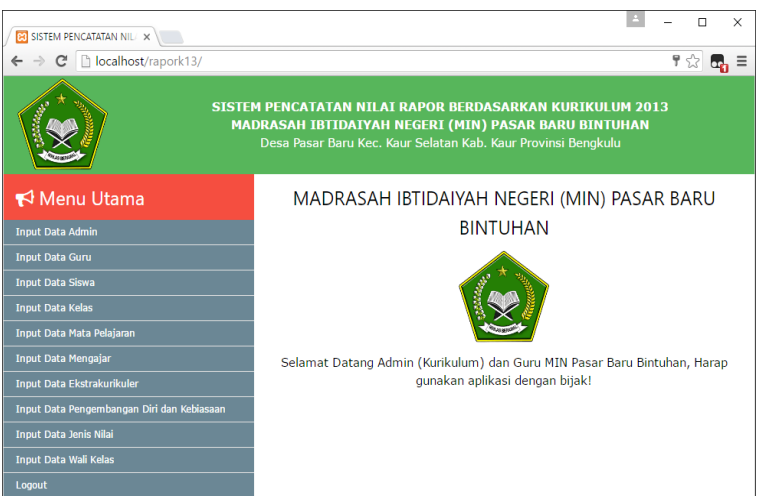

\section{Login Guru dan Wali Kelas}

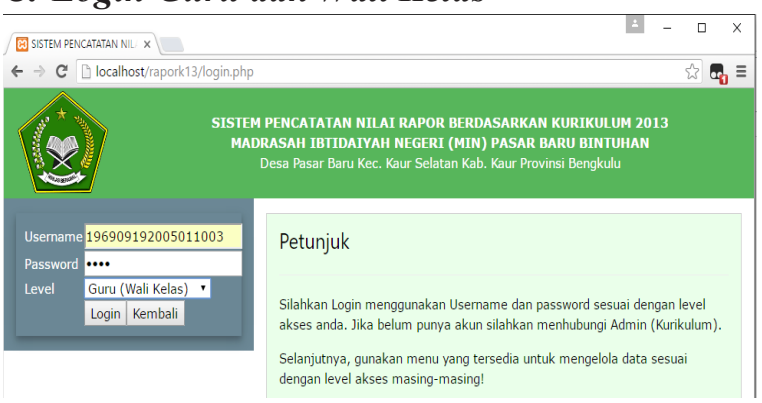

\section{Menu Utama Guru dan Wali Kelas}

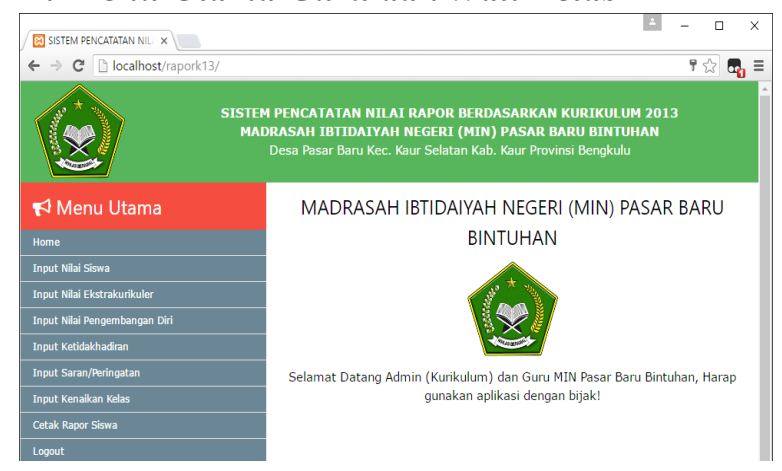




\section{E. Cetak Laporan}

\section{Cetak Laporan}

\section{Laporan Data Guru : Cetak}

2. Laporan Data Siswa

Pilih Kelas : $1 \vee$ Cetak

\section{1) Laporan Data Guru}

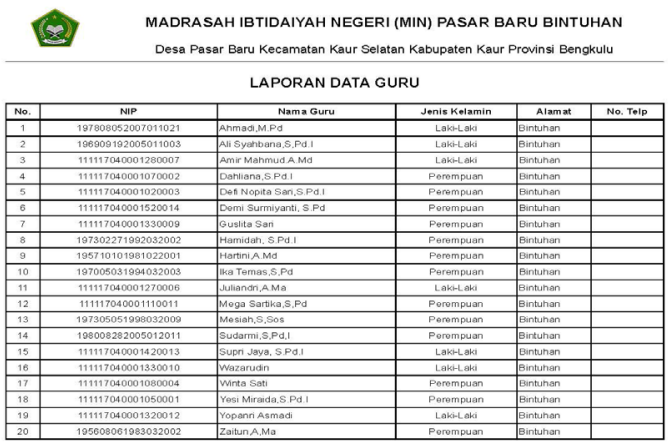

Bintuhan. 16 Juni 2016
Ka. Kurikulum,

$$
\overline{\text { NIK. }}
$$

\section{2) Laporan Data Siswa}

(2) MADRASAH IBTIDAIYAH NEGERI (MIN) PASAR BARU BINTUHAN Desa Pasar Baru Kecamatan Kaur Selatan Kabupaten Kaur Provinsi Bengkulu

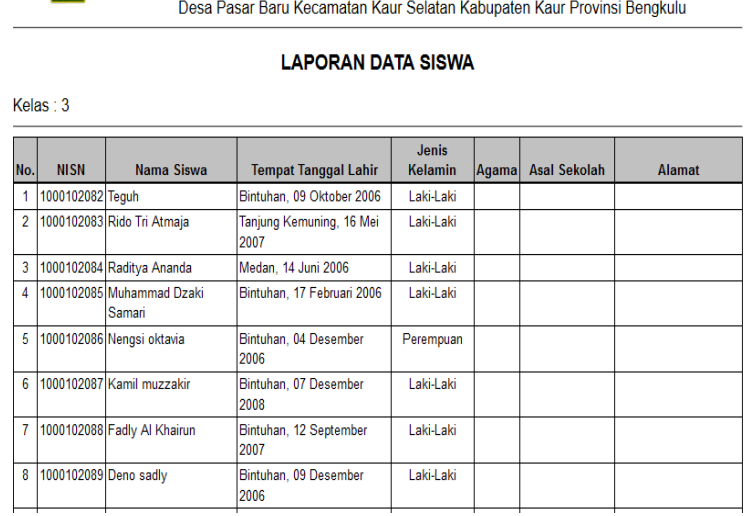

\section{F. Keterangan Tentang Siswa}

KETERANGAN TENTANG DIRI SISWA

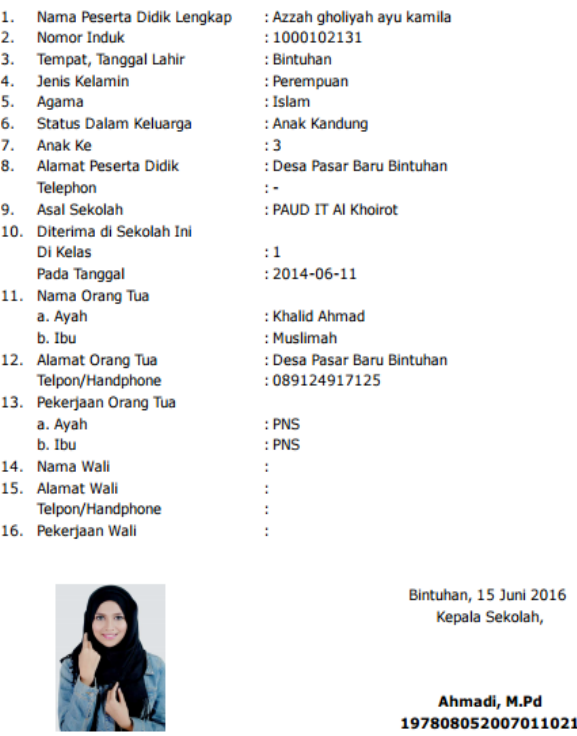

\section{G. Rapor Siswa}

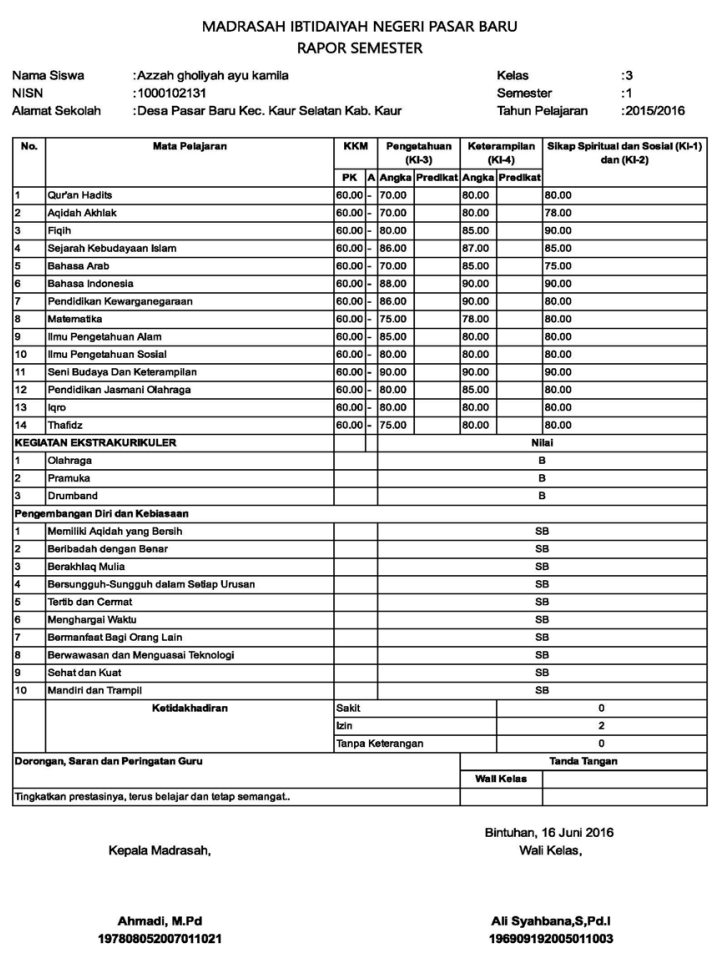




\section{KESIMPULAN DAN SARAN}

\section{A. Kesimpulan}

Sesuai dengan uraian program dan hasil pengujian sistem yang telah dilakukan maka dapat disimpulkan :

1. Bahasa pemrograman PHP dan database MySQL dapat digunakan untuk mengembangkan aplikasi yang bermanfaat bagi pengelolaan rapor siswa pada MIN Pasar Baru Bintuhan

2. Aplikasi Sistem Pencatatan Penilaian Rapor Siswa Berdasarkan Kurikulum 2013 pada MIN Pasar Baru Bintuhan telah berjalan dengan baik sesuai dengan yang direncanakan pada perancangan sistem.

3. Pengelolaan rapor di MIN Pasar Baru Bintuhan menjadi lebih efektif dengan menggunakan aplikasi pencatatan nilai rapor ini.

\section{B. Saran}

Dari uraian kesimpulan pada sub bab sebelumnya, penulis memberikan saran sebagai berikut:

1. Bagi MIN Pasar Baru Bintuhan untuk dapat menggunakan Aplikasi Sistem Pencatatan Penilaian Rapor Siswa supaya pengelolaan rapor lebih efektif.

2. Semua guru dan wali kelas yang terlibat dalam penggunaan aplikasi ini sebaiknya diberikan pelatihan terlebih dahulu sehingga tidak ada masalah saat pengelolaan rapor siswa.

3. Bagi pembaca, hasil penelitian ini dapat digunakan sebagai referensi untuk perkembangan penelitian berikutnya yang terkait dengan sistem pencatatan rapor siswa.

\section{DAFTAR PUSTAKA}

Febrian, Jack, 2004, Pengetahuan Komputer dan Teknologi Informasi, Informatika, Bandung

Koniyo, Andri. Kusrini, 2007, Tuntunan Praktis Membangun Sistem Informasi Akuntansi dengan Visual Basic dan Microsoft SQL Server, CV. Andi Offset, Yogyakarta

Oktavian, D.P., 2010, Menjadi Programmer Jempolan Menggunakan PHP, MediaKom, Yogyakarta.

Simarmata J dan Paryudi J, 2006, "Basis Data" Penerbit Andi Yogyakarta.

Sutabri Tata, 2004, Analisa Sistem Informasi, Andi Yogyakarta.

Yakup, 2012, Pengantar Sistem Informasi, Graha Ilmu. Yogyakarta.

Yuhefizard, 2008, Database Management Menggunakan Microsoft Access 2003, PT. Elex Media Komputindo, Jakarta. 